Клименко, О., Москаленко, Л. (2020). Трансформація освітніх практик в умовах кризи: реалії українського суспільства. Соціологічні студї, 1 (16), 14-21. DOI: https://doi.org/10.29038/2306-3971-2020-01-14-21

\title{
Трансформація освітніх практик в умовах кризи: реалії українського суспільства
}

\author{
Олена Клименко - \\ доктор сои. наук, доцент, \\ професор кафедри економіки, \\ підприсмництва та сочіальних \\ технологій, Державний \\ університет телекомунікацій, \\ Киів, Україна.
}

\section{Elena Klymenko -}

PhD in Sociology, Professor,

Department of Economics,

Entrepreneurship and Social

Technologies, State University

of Telecommunications,

Kyiv, Ukraine.

E-mail: klimenkoelens@gmail.com

ORCID: https://orcid.org/0000-00028560-8642

\section{Лариса Москаленко -}

канд. філос. наук, доиент кафедри економіки, підприємництва та сочіальних технологій, Державний університет телекомунікаиій,

Киів, Україна.

\section{Larysa Moskalenko -}

PhD in Philosophy, Associate

Professor, Department

of Economics, Entrepreneurship

and Social Technologies, State

University of Telecommunications,

Kyiv, Ukraine.

E-mail:

larisamoskalenko292@gmail.com

ORCID: https://orcid.org/0000-0003-

0202-3479

DOI: https://doi.org/10.29038/2306-

3971-2020-01-14-21

Reseived: May, 2020

$I^{\text {st }}$ Revision: June, 2020

Accepted: June, 2020
Мета статті - вивчення нових моделей освітніх практик, які стали найбільш поширеними в кризовий період під час упровадження карантину та вимушеної самоізоляції в українському суспільстві й визначення ролі онлайн-навчання під час формування стратегій адаптації до умов обмеження соціальної активності. Оскільки ця проблема на сьогодні є актуальною для українського суспільства, яке намагається адаптуватися до принципово нових реалій життя, зумовлених карантинними обмеженнями й високим рівнем ризиків для здоров'я громадян, автори провели власне соціологічне дослідження із застосуванням методу Інтернет-опитування населення м. Києва та Київської області щодо змін освітніх практик в умовах кризи. Особливу увагу приділено вивченню вікових особливостей усвідомлення й сприйняття онлайн-освіти, а також аналізу нових освітніх практик, котрі стали використовувати комплексно разом із традиційними. Дослідження реакції пересічних громадян на кризу та вивчення моделей адаптації суспільства в реаліях сьогодення дало змогу авторам переглянути процеси вибору особистістю стилів поведінки, стратегій соціальної дії та освітніх практик, акцентувавши увагу на тому, що раніше напрацьовані методи пристосування не спрацьовують, а соціальна реальність потребує створення нових моделей адаптації.

Klymenko Elena, Moskalenko Larysa. Transformation of Educational Practices in a Crisis: the Realities of Ukrainian Society. The aim of the article is to study new models of educational practices that became the most 
common in Ukrainian society during the period of crisis associated with quarantine conditions, accompanied by forced self-isolation of citizens and determining roles in online learning, allowing formulating new strategies for adapting to the conditions of limiting social activity. Since this problem is currently relevant for the Ukrainian society, which is trying to adapt to fundamentally new realities of life, due to quarantine restrictions and a high level of risks to the health of citizens, the authors conducted their own sociological research using the method of Internet survey of the population of Kiev and Kiev region. Its results made it possible to identify trends in the educational practices of Ukrainians under quarantine. Particular attention is paid to the study of age-related features of awareness and perception of online education, as well as the analysis of new educational practices that have begun to be applied comprehensively with the old ones. The study of the reaction of ordinary citizens to the crisis and the study of models of society's adaptation to existing realities allowed the authors to review the processes of personality choice of behavioral strategies, social action strategies, and educational practices, focusing on the fact that previously developed adaptation methods do not work, and social reality requires the creation of new adaptation models.

The results of a sociological study fully confirmed the hypothesis about the essential role of educational practices in society. Non-formal education has become a mechanism for Ukrainians to adapt to crisis phenomena and social transformations. There was a tendency towards an increase in the interest of the older age group in non-formal types of education and a decrease in the interest of young people in formal education, which turned out to be unprepared for such challenges as the transition to on-line. The complex of crises that Ukrainian society is experiencing has become a certain impetus for ordinary citizens to improve the mechanisms of social adaptation, one of which under the fundamentally new living conditions was non-formal education.

Key words: crisis, education, life strategies, adaptation models, distance learning

Клименко Елена, Москаленко Лариса. Трансформации образовательных практик в условиях кризиса: реалии украинского общества. Цель статьи - изучение новых моделей образовательных практик, которые стали наиболее распространенными в украинском обществе во время периода кризиса, связанного с условиями карантина, сопровождающегося вынужденной самоизоляцией граждан и определяющего роли в онлайн-обучении, позволяющие сформировать новые стратегии адаптации к условиям ограничения социальной активности. Поскольку данная проблема на сегодня является актуальной для украинского общества, которое пытается адаптироваться к принципиально новым реалиям жизни, обусловленным карантинными ограничениями и высоким уровнем рисков для здоровья граждан, нами проводилось социологическое исследование с использованием метода Интернет-опроса населения г. Киева и Киевской области. Его результаты позволили выделить тенденции изменения образовательных практик украинцев в условиях карантина. Особое внимание уделяется изучению возрастных особенностей осознания и восприятия онлайн-образования, а также анализа новых образовательных практик, которые стали применять комплексно со старыми. Исследование реакции рядовых граждан на кризис и изучение моделей адаптации общества к существующим реалиям сделало возможным пересмотр процессов выбора личностью стилей поведения, стратегий социального действия и образовательных практик, акцентировав внимание на том, что ранее наработанные методы приспособления не срабатывают, а социальная реальность требует создания новых моделей адаптации.

Ключевые слова: кризис, образование, жизненные стратегии, модели адаптации, дистанционное обучение.

Постановка наукової проблеми та їі значення, актуальність дослідження. У 2020 р. криза стала головною проблемою не лише для політиків, державних службовців, політологів, соціологів, але й для більшості простих громадян, оскільки так чи інакше вона стосується всіх сфер життя як українського суспільства, зокрема, так і Світового Співтовариства загалом. Нині майже не залишилося людини, на соціальних діях якої не позначилося б розповсюдження страшної хвороби COVID-19 та вимушені обмеження, пов'язані з упровадженням карантинних заходів. Специфічною рисою для України стала ситуація, за якої світові тенденції вплинули на вже наявну затяжну системну кризу українського суспільства, що своїм корінням сягає подій 2014 р. Низка криз військово-політичного, економічного, культурного характеру, які впродовж останніх шести років супроводжують життя українців, поєдналися з глобальною - світовою, зумовленою пандемією, що створило ситуацію високого рівня загрози національній безпеці. За даними $\mathrm{OOH}$, понад 6 млн українців опинилися за межею бідності (рівень якої зріс із 27 до 44 \%), при цьому кожна друга сім'я потрапила в зону ризику, найбільш уразливими нині $€$ неповні родини та сім'ї з маленькими дітьми (понад 6 млн, 2020).

За останні роки в українському суспільстві напрацьовано способи пристосування людей до життя в кризових ситуаціях, серед яких є як пасивні, так і активні моделі адаптації. Умови карантину 
не просто обмежили можливості до пересування та спілкування людей, змушуючи пересічних громадян здебільшого відмовитися від традиційних соціальних дій і перейти до раціональних, вони різко скоротили перелік можливих технологій адаптації особистості, оскільки змінили часовопросторовий конструкт життя. Сдиним простором, який більш-менш залишився стабільним і для якого час не має значення, є Інтернет.

За активної моделі адаптації до принципово нових соціальних реалій віртуальний простір використовується людиною як середовище, через яке й безпосередньо в якому можна знайти собі роботу, додаткові можливості для заробітку, нові способи самореалізації та отримати необхідні знання. В іншому випадку віртуальне середовище може виступати засобом пасивної моделі пристосування до життя за умов кризи шляхом спілкування в Інтернет-співтоваристві, прослуховування музики, перегляду фільмів, читання художньої літератури, ознайомлення з інформаційними сайтами.

Трансформації в житті суспільства актуалізували питання масового переходу освітніх практик у віртуальний простір. За даними ЮНЕСКО, через COVID-19 карантинні заходи ввели 165 країн, саме тому понад 1,5 млрд осіб (91,4 \%) перейшли на дистанційне навчання, хоча, за даними Організації 3 економічної співпраці (OECD), лише 53 \% викладачів мають досвід проведення онлайн-навчання (Обучение продолжается..., 2020). Зрозуміло, що освітні заклади були змушені перейти на дистанційні форми навчання, однак не менш цікавим є досвід залучення молоді та людей середнього віку до неформальної освіти в Інтернет-мережі як варіант максимально ефективного використання вимушено вивільненого карантином часу задля самовдосконалення.

Аналіз основних досліджень цієї проблеми (теоретичні засади дослідження, методологія та характеристика емпіричної бази). Усвідомлення змін просторово-часових характеристик соціальної реальності в соціології пов'язано з концепцією формування нового стану світової цивілізації, яку У. Бек позначив як стан «Глобальності». У іiі основу покладено розуміння особистістю неможливості замкнути соціальний простір через спільність будь-яких соціальних відносин, які вже не можуть бути процесами національно-державного масштабу, оскільки, завдяки швидкому розповсюдженню інформації, вони неминуче стають надбанням світової спільноти. До найбільш очевидних наслідків подібного стану У. Бек відносить швидке розповсюдження наукової та навчальної інформації (Бек, 2000, с. 26).

Теорію криз і соціальних змін розроблено в перше десятиліття XX ст. відомим американським соціологом К. Томасом. Криза, на його думку, - це явище, яке «порушує звичний хід речей» і вимагає від людини формування «нової моделі поведінки» для пристосування своїх дій до нових умов зміненої соціальної реальності. Науковець підкреслював три основні чинники, наявність яких сприяє успішному подоланню кризи соціальною групою, а саме: присутність лідерів; достатній рівень розвитку групи, у тому числі наявність необхідних технологій, а головне - прагнення до прогресу й гнучкість сприйняття об'єктивної реальності (Томас, 2012, с. 21).

Етапи формування концепцій кризи в соціологічній теорії можна умовно поділити на три історичні періоди.

Перший період - від початку ХХ ст. приблизно до середини 1970-х рр. У цей час відбувається безпосереднє формування концепції «кризи» як соціального явища, на що звернули увагу К. Томас, О. Богданов, П. Сорокін, Ю. Хабермас. Паралельно виникає низка наукових теорій, котрі вивчають соціальні катастрофи відокремлено від кризових явищ, їхніми авторами були Г. Прінс, Л. Карр, Р. Кутак.

Другий період починається із середини 1970-х рр. і триває до кінця ХХ ст., характеризується обгрунтуванням такого поняття, як «кризове управління» в рамках теорії кризи, дослідженням якого займалися Р. Сталлінгс, Р. Дайнз і Е. Карантеллі. Основним науковим доробком зазначених авторів стало узагальнення концепції кризи, що дало змогу використовувати висновки соціологічних досліджень у менеджменті й адмініструванні, а також сприяло появі методології кризового управлінця.

Третій період, що формується з початку XXI ст. та триває по сьогодні, бере свій початок від спроби створення науковцями інтегральної концепції кризи й кризового управління, проведення міждисциплінарних досліджень, завдяки яким виникають нові наукові парадигми - «складного соціуму» (Грызунова, 2020). Вони сприяють створенню спеціальних термінів, необхідних для 
пояснення нових кризових явищ. У зазначеній царині наукового пошуку працюють Е. Карантеллі, А. Бойн, Е. Андерсон.

Отже, дослідження криз і вивчення моделей адаптації до них суспільства для соціології не $є$ новим, однак реалії сьогодення зумовили необхідність перегляду деяких аспектів через виникнення ситуації, за якої одна криза накладається на декілька вже наявних, що ускладнює процеси вибору особистістю стилів поведінки, докорінно змінюючи стратегії соціальної дії, оскільки раніше напрацьовані методи пристосування не діють, а соціальна реальність потребує створення нових моделей адаптації.

Емпіричну базу статті становили дані проведеного авторами соціологічного дослідження, а саме результати Інтернет-опитування населення м. Києва та Київської області, яке відбулося 3 27 квітня по 11 травня 2020 р. Метод збору інформації - заповнення google-форми за фактом відвідування Інтернет-платформи. Загалом, опитано 441 респондента віком від 17 до 60 років. Вибіркова сукупність стихійна, на останньому етапі здійснювався квотний добір за основними соціально-демографічними характеристиками дорослого населення України (стать, вік, тип населеного пункту, рівень освіти). Для порівняння основних показників респондентів умовно розподілено на дві вікові групи: 17-25 років - молодь, яка вимушена навчатися дистанційно, і 26-60 років - ті, котрі самостійно здобувають знання задля підвищення кваліфікації й розширення особистого світогляду. Респонденти мають різний рівень освіти: повна загальна середня освіта $-42,9 \%$, вища освіта $29,9 \%$, неповна та базова вища - 16,1 \%, професійно-технічна освіта $-5,0 \%$, базова вища, базова (неповна середня) $-3,4 \%$, науковий ступінь - 1,1\%.

Анкета складалася з двох основних змістових блоків - побутово-дозвіллєві та освітні практики, кожен із яких містив по сім запитань, та соціально-демографічного, у якому респонденти надавали інформацію про стать, вік, освіту й місце проживання.

Розглядаючи кризу як певний імпульс до розвитку суспільства, аналізуючи не лише ії негативні, але й позитивні чинники, ми намагалися проаналізувати, який шлях адаптації (активний чи пасивний) до принципово нових умов життя оберуть пересічні громадяни.

Мета статті - дослідження нових моделей освітніх практик, які стали найбільш поширеними в кризовий період упровадження карантину та вимушеної самоізоляції в українському суспільстві й визначення ролі онлайн-навчання під час формування стратегій адаптації до умов обмеження соціальної активності.

Виклад основного матеріалу й обгрунтування отриманих результатів дослідження. Навесні 2020 р. більшість українців опинилася в карантинному обмеженні або в самоізоляції без можливості не лише подорожувати, але й загалом вести звичний спосіб життя. Зміни традиційних соціальних практик призвели до того, що вивільнилася значна кількість часу, який люди змушені були проводити в обмеженому просторі разом із членами своєї сім’ї, яких до цього бачили тільки вранці та ввечері. Така ситуація визначила необхідність створення нових схем організації життя й переносу роботи та навчання в онлайн-формат. За результатами проведеного дослідження, кожен другий 3 опитаних $(54,2 \%)$ зазначив, що умови карантину сприяли зміні побутових звичок. Суттєвих відмінностей у відповідях на це запитання між респондентами різних вікових і соціально-демографічних груп не виявлено.

Цілісна система соціального життя, яка раніше мала свою просторову архітектоніку, була повністю зруйнована умовами довготривалої вимушеної ізоляції, докорінно змінивши ставлення до матеріальних речей, міжособових стосунків, трансформувавши принципи соціальної взаємодії, соціальні зв'язки й зміст, зафіксований у системі суспільно значущих ідей. Пересічні громадяни змушені налагоджувати принципово нові моделі суспільної праці та навчання. Підтвердження цього - розподіл відповідей на запитання щодо продовження своєї професійної діяльності під час карантину. Так, лише $21,8 \%$ респондентів зазначили, що їхні робочий графік та режим праці не зазнали радикальних змін, 40,6 \% у період карантину продовжували свою професійну діяльність, перейшовши на дистанційну форму співпраці, 30,2 \% респондентів у період карантину змушені були перервати професійну діяльність, а 7,5 \% визнали, що не працювали й раніше.

Наведені дані підтверджує офіційна статистика. Під час карантину статус «безробітного» отримали 156 тис. українців, що втричі більше, ніж у цей же час у 2019 р. Загальна чисельність 
безробітних, за офіційними даними, становить 490,5 тис. Матеріальну допомогу по безробіттю, яка раніше становила 650 грн, збільшили до 1000 грн, що посилило навантаження на бюджет. Кількість же вакансій на біржах праці зменшилася на 60 \% (В Україні з..., 2020).

Специфіка соціального простору тісно пов'язана зі специфікою соціального часу, який $\epsilon$ внутрішнім виміром суспільного життя, котрий вимушений спиратися на фізичні ритми протікання природних процесів. Соціальний час - це кількісна оцінка шляху, пройденого суспільством. Він $\epsilon$ мірою мінливості соціальних процесів та змін, які історично виникають у житті людей. Криза, котру переживає українське суспільство, змінила розуміння соціального простору й часу, обмеживши їх безпосередніми умовами життя конкретних осіб та перевівши комунікацію із соціумом із реального трьохвимірного простору до Інтернет-середовища. Найсуттєвіших змін у зазначеному контексті зазнала освіта, яка була змушена докорінно змінити методи надання освітніх послуг, повністю трансформувавши процес формування знань, навичок i вмінь, залишивши незмінною лише необхідну якість результатів навчання. 3 останньою в українській освіті ще до карантину виникали серйозні проблеми. Отже, в Україні кризові тенденції, пов'язані з упровадженими карантинними заходами від COVID-19, вплинули на вже наявні соціальні проблеми.

Нові виклики та нові соціальні моделі поведінки (за результатами соціологічного дослідження). В умовах життя, коли ні середовище проживання, ні простір, у якому відбувається соціальна взаємодія, не змінюються впродовж тривалого часу, людина починає звикати до парадоксів життя, що пї оточують.

Феномен звикання - один із пасивних механізмів адаптації особистості до нових умов і способу життя. Однак його змістовне наповнення може бути як позитивним, так і негативним. Залежно від того, яким шляхом піде особистість, вона обиратиме й форми соціальної взаємодії від традиційних способів організації повсякдення (диван та перегляд телевізійних програм, комп’ютер і соціальні мережі) до радикальних змін у побуті (косметичний ремонт, нове хобі). Результати проведеного соціологічного дослідження свідчать, що українці здебільшого обирають більш активні форми адаптації.

На запитання «Яким видам діяльності під час карантину/самоізоляції Ви надавали перевагу?» (передбачено можливість обрати не більше трьох варіантів) відповіді респондентів розподілилися таким чином: 49,1 \% зазначили, що в період карантину навчалися й/або підвищували кваліфікацію; $48,4 \%$ - більше уваги приділили спорту та покращили свій фізичний стан; $46,4 \%$ - у вільний час займалися хатньою роботою (прибирання, ремонт); 34,2 \% - вимушену ізоляцію й соціальну дистанцію компенсували спілкуванням 3 оточенням, використовуючи digital-ресурси (соціальні мережі, групи за інтересами в різноманітних Інтернет-платформах). Майже кожен третій $(30,2 \%) 3$ опитаних зазначив, що в період карантину надав перевагу кулінарії (приготуванню їжі), 29,3% розважалися (долучалися до комп'ютерних ігор, командних віртуальних змагань, перегляду Інтернет-контенту), 18,9\% - підвищували свій культурний рівень, а $11,0 \%$ - займалися присадибним господарством.

Аналіз відповідей респондентів щодо виявлених моделей поведінки (видів діяльності) у період нових соціальних реалій демонструє деяку розбіжність за віковими ознаками у виборі адаптаційних стратегій. Вікова група від 17 до 25 років була найбільш мотивованою до онлайн-навчання, вочевидь, щоб уникнути хатніх робіт та додаткового побутового навантаження, скориставшись часом для навчання з метою спілкування з однолітками в соціальних мережах. Так, за результатами дослідження, 63,0 \% молодих людей у період карантину були залучені до навчання, 54,2 \% - віддали перевагу фізичним тренуванням, 39,3\% - відверто зізналися, що налагоджували комунікацію 3 навколишніми, використовуючи digital-ресурси. Такий високий показник залученості до навчання, передусім, пояснюється вимогою формальних закладів освіти (шкіл та університетів) у період карантину продовжувати навчання в дистанційній формі; по-друге, саме ця соціально-демографічна група опинилася найменш захищеною в період трансформацій і криз. Тому для молоді освіта виступила механізмом адаптації до нових соціальних реалій.

Респонденти старшої вікової соціально-демографічної групи - від 26 до 50 років зазначили, що в період карантину популярними видами діяльності для них були хатні роботи $(59,0$ \%), заняття 
фізичними тренуваннями (37,0 \%), кулінарія (приготування їжі) (35,0 \%). Вочевидь, ці два показники взаємопов'язані й передбачають один одного. Однак цікавим став той факт, що 30,6 \% представників зазначеної вікової групи активно використовували вільний час для навчання та підвищення кваліфікації.

Можливо, такий високий рівень залученості до освітніх практик пов'язаний із великим професійним запитом. За даними соціологічного дослідження, найбільш затребувані в професійному плані в період карантину були респонденти саме старшої соціально-демографічної групи віком від 26 до 50 років. Так, 71,5\% опитаних зазначили, що продовжували свою професійну діяльність офлайн чи дистанційно. У віковій групі від 17 до 25 років змогли втриматися на своєму робочому місці лише 55,8 \% молоді, із яких 23,3 \% зазначили, що перейшли в онлайн-режим.

Отже, для більшості молодих людей феномен звикання до кризової ситуації як організація життя особистості в умовах украй обмежених ресурсів, і економічних, і соціальних, став пусковим механізмом до радикальних змін форм активності, що призвело до зміни сприйняття соціального простору який із трьохвимірного став одномірним. Оскільки в умовах дефіциту практик соціальної взаємодії та відсутності напрацьованих адаптаційних стратегій молодь спрямовує основну увагу на збереження вже наявного потенціалу, а тому зводить соціальні дії до банального задоволення базових потреб. Уся життєдіяльність зосереджується навколо того, щоб відтворити себе фізично й приємно провести час. Тому близько 30 \% опитаних повністю ігнорували необхідність брати участь у дистанційному навчанні. На питання «Чи знайшли Ви для себе цікаве заняття під час карантину?» $22,7 \%$ було складно відповісти, $36,7 \%$ - не знайшли, а от $40,6 \%$ змогли чимось зацікавитися (більшість із них відкрила для себе можливості фізичної культури).

Відзначимо, що суттєвих відмінностей у відповідях вікових категорій на запитання щодо ставлення до карантину не зафіксовано. На запитання «Чи подобається Вам стиль життя, який сформувався у Вас під час карантину/самоізоляції?» ствердно відповіли лише 20,4\% 3 усіх респондентів. Цікаво, що кожен третій $(34,0 \%)$ із тих респондентів, які в період карантину перебували на віддаленій роботі, відзначили, що подібний стиль життя їм подобається. Але більшість українців (75,3 \%) зазначили, що стиль життя, сформований під час карантину, їм не подобається. Це підтверджують дослідження Київського міжнародного інституту соціології, за результатами яких під час карантину лише 45,0 \% українців вважали себе цілком щасливими (Паніото, 2020).

Цікаво, що зміни, які відбулися в соціальних практиках українців під час карантину, не вплинули на розподіл гендерних ролей у веденні домашнього господарства. У цій царині побутового життя суспільство обрало дії винятково традиційного характеру. Отож 80,0\% опитаних жінок продовжували займатися кулінарією (готувати), 70,5 \% - виконували хатні роботи, а от працювати на присадибних ділянках почали $50,0 \%$ чоловіків, обов'язки розподілилися навпіл. Можливо, останне зумовлено бажанням збільшити час перебування на свіжому повітрі.

В умовах кризи особистість під час соціальної взаємодії не може будувати свої життєві стратегії звичним шляхом, оскільки для цього в неї не вистачає ресурсів: матеріальних, соціальних, психологічних. Це різко скорочує варіанти їі життєвих виборів, змушує корегувати соціальну поведінку, обмежуючи їі короткими життєвими проектами, які грунтуються на безпосередніх можливостях. На таке явище звернув увагу В. Кривошеєв, який зазначив, що зворотною стороною адаптації під час кризи може стати деривація, яка гаситиме соціальні конфлікти (Кривошеев, 2009).

У цьому сенсі освіта $\epsilon$ не просто дієвим механізмом адаптації до кардинально змінених умов життя, а виступає як певний стабілізатор життєвих практик. За даними соціологічних досліджень КМІС, рівень щастя прямо пропорційний рівню освіти: чим вища освіта - тим вищий рівень щастя. Так, серед людей із неповною середньою освітою, щасливими себе вважають 50 \% опитаних, серед людей із вищою освітою - 77 \% (Паніото, 2020).

Адаптаційна функція навчання в період трансформацій та криз. Як зазначено вище, навчання в період упровадження карантину стало найбільш популярним видом діяльності, на яку українці витрачали свій вільний час. Загалом, майже кожен другий $(49,1 \%$ опитаних) під час вимушеної самоізоляції навчалися. Однією з причин такої популярності була вимога формальних закладів освіти продовжувати навчання дистанційно. Однак 32,9 \% зазначили, що долучилися до навчання, мотивовані власним бажанням особистісного росту, а $29,5 \%$ - із метою професійного зростання. 
Крім того, з'ясовано, що 17,6 \% респондентів навчалися, тому що з'явився вільний час, 12,6 \% мотивовані можливістю безкоштовно долучитися до курсів кращих університетів світу й платформ, які раніше були платними та 10,6 \% - зізналися, що долучилися до навчання від нудьги.

Аналіз мотивації щодо освітніх практик різних вікових груп демонструє інші пріоритети. $34,4 \%$ молодих людей віком від 17 до 25 років зазначили, що основною мотивацією до навчання стало бажання особистісного росту, а для $29,4 \%$ - професійне зростання. Саме в цій соціально-демографічній групі відзначено значний показник респондентів $(13,7$ \%), які долучилися до навчання від нудьги.

Водночас майже кожен третій (30,0 \% опитаних) зі старшої соціально-демографічної групи під час карантину долучалися до навчання, стільки ж із тих, хто навчався, зазначили, що основною мотивацією стало бажання особистісного росту; а $28,4 \%$ - прагнули професійного вдосконалення, $20 \%$ - долучилися до навчання від нудьги.

Отже, результати проведеного соціологічного дослідження демонструють високий потенціал освіти як механізму адаптації до соціальних змін у кризових ситуаціях, за умов просторово-часової дезорієнтації та відмови від традиційних форм соціальної взаємодії, що $є$ актуальним для всіх вікових груп сучасного українського суспільства.

Висновки та перспективи подальших досліджень. Результати соціологічного дослідження цілком підтвердили нашу гіпотезу про суттєву роль освітніх практик у житті суспільства, які для окремих людей стали механізмом адаптації до кризових явищ. Довготривале перебування в умовах карантину змінило просторове й часове сприйняття особистістю соціальної реальності. Паралельно зафіксовано тенденцію до збільшення зацікавленості старшої вікової групи в неформальних видах освіти та зменшення інтересу молоді до формальної освіти, яка виявилася не готовою до таких викликів, як перехід в он-лайн. Кризові явища не вплинули на більшість повсякденних побутових життєвих практик українців усіх вікових категорій, вони залишились незмінними. Головна роль у виконанні домашніх робіт і приготуванні їжі залишилася за жінками.

Комплекс криз, які переживає українське суспільство, став певним поштовхом для пересічних громадян для вдосконалення механізмів соціальної адаптації, одним із яких за принципово нових умов життя стала неформальна освіта. Однак окреслене проблемне поле потребує подальших наукових розвідок і більш детальних соціологічних досліджень. Потенційно актуальними тривалий час будуть питання особливостей соціальної взаємодії й комунікації в безконтактному суспільстві, радикальна зміна споживчих та дозвіллєвих практик. Перехід бізнесу в онлайн-режим сприятиме вже добровільному дистанціюванню працівників, для більшості з яких власна домівка стане офісом, що сприятиме виникненню безлічі соціальних проблем, які потребуватимуть наукового осмислення.

\section{Джерела та література}

1. Бек, У. (2000). Общество риска. На пути к другому модерну. [Пер. с нем. В. Седельника, Н. Федоровой]. Москва: Прогресс-Традиция. 383 с.

2. Більше 6 млн. українців можуть опинитися за межею бідності (2020). Отримано 14 травня 20203 https://business.ua/news/10146-bilshe-6-mln-ukrajintsiv-mozhut-opinitisya-za-mezheyu-bidnosti

3. В Україні з початку карантину кількість безробітних зросла у 1,5 рази (2020). Отримано 5 травня $20203 \mathrm{https} / / /$ glavcom.ua/economics/finances/v-ukrajini-z-pochatku-karantinu-kilkist-bezrobitnih-zrosla-u15-razi-677870.html

4. Грызунова, Е. А. (2020). Концепции кризиса социальной системы: сравнительный анализ. Свежсий взгляд. Получено 16 марта 2020 c https://www.academia.edu/3461425/Концепции_кризиса_социальной_ системы_сравнительный_анализ

5. Кривошев, В. В. (2009). Короткие жизненные проекты: проявление аномии в современном обществе Социологические исследования. 3, 58-69.

6. Обучение продолжается: ЮНЕСКО объединяет международные организации, гражданское общество и партнеров из частного сектора в широкую Коалицию по вопросам образования (2020). Получено 26 марта $2020 \mathrm{c} \mathrm{https://ru.unesco.org/news/obuchenieprodolzhaetsya-yunesko-obedinyaet-mezhdunarodnye-}$ organizacii-grazhdanskoe-obshchestvo

7. Паніото, В. (2020). Самооцінка щастя населенням України: квітень 2020. Отримано 18 травня 20203 https://www.kiis.com.ua/?lang=ukr\&cat=reports\&id=944\&page $=1 \& \mathrm{t}=7$

8. Томас, К. (2012). Кризис и возникновение научных теорий. Исследователь. 1-2, 20-39. Получено 26 марта 2020 c https://cyberleninka.ru/article/n/krizis-i-vozniknovenie-nauchnyh-teoriy 


\section{References}

1. Beck, W. (2000). Risk Society. On the way to another Art Nouveau. [Transl. by B. Sedelnik, N. Fedorova]. Moscow: Progress-Tradition, $383 \mathrm{p}$.

2. More than 6 million Ukrainians may find themselves below the poverty line (2020). Retrieved May 14, 2020 from https://business.ua/news/10146-bilshe-6-mln-ukrajintsiv-mozhut-opinitisya-za-mezheyu-bidnosti

3. In Ukraine, the number of unemployed has increased 1.5 times since the beginning of quarantine (2020). Retrieved May 5, 2020 from https://glavcom.ua/economics/finances/v-ukrajini-z-pochatku-karantinu-kilkistbezrobitnih-zrosla-u-15-razi-677870.html

4. Gryzunova, E. A. (2020). Concepts of crisis of social system: the comparative analysis. Fresh look. Retrieved March 16, 2020 from https://www.academia.edu/3461425/Концепции_кризиса_социальной_системы_ сравнительный_анализ

5. Krivosheev, V. V. (2009). Short life projects: manifestation of anomie in modern society Sociological research. 3, 58-69.

6. Training continues: UNESCO brings together international organizations, civil society and private sector partners into a broad Coalition for Education (2020). Retrieved March 26, 2020 from https://ru.unesco.org/ news/obuchenieprodolzhaetsya-yunesko-obedinyaet-mezhdunarodnye-organizacii-grazhdanskoe-obshchestvo

7. Panioto, V. (2020). Self-assessment of happiness by the population of Ukraine: April 2020. Retrieved May 18, 2020 from https://www.kiis.com.ua/?lang=ukr\&cat=reports\&id=944\&page=1\&t=7

8. Thomas, K. (2012). The Crisis and Emergence of Scientific Theories. Researcher, 1-2, 20-39. Retrieved March 26, 2020 from https://cyberleninka.ru/article/n/krizis-i-vozniknovenie-nauchnyh-teoriy 